\title{
EARLY CHILDHOOD READING: A SUBJECT GENERATING PRACTICE
}

\section{ORIGINAL ARTICLE}

OLIVEIRA, Leandro Ribeiro de ${ }^{1}$

TOLEDO, Luciana Renata de ${ }^{2}$

OLIVEIRA, Leandro Ribeiro de. TOLEDO, Luciana Renata de. Early childhood reading: a subject generating practice. Revista Científica Multidisciplinar Núcleo do Conhecimento. Year 05, Ed. 05, Vol. 09, pp. 83-93. June 2020. ISSN:2448-0959, Access link in: https://www.nucleodoconhecimento.com.br/education/early-childhood

\section{ABSTRACT}

In the last two decades, Brazil has experienced a series of changes in its education system seeking to contribute to the quality of education and the increase in learning rates. Despite all efforts, the results appear to remain below expectations, especially in terms of reading. In the process of collaborating in the task of arousing interest in books, developmental psychology, based on the studies of Jean Piaget and Lev Vygotsky, becomes a rich tool for the teacher in the classroom, especially even in the first childhood. In this sense, the present study aimed to observe the first contacts of a child with the book and to raise hypotheses about the impacts that this practice causes when minors are exposed to reading activity from an early age. This way, the research unfolds under the bias of the inductive method, since this part of the observation of

\footnotetext{
${ }_{1}^{1}$ Pós-graduado em Cultura e Literatura, pela Faculdade São Luís, de Jaboticabal, São Paulo. Graduado em Letras, pelo Instituto Municipal de Ensino Superior - Faculdade de Filosofia, Ciências e Letras (IMES-FAFICA), de Catanduva, São Paulo.

2 Pós-graduada em Alfabetização e Letramento, pela Faculdade de Tecnologia Paulista, de Lupércio, São Paulo. Graduado em Pedagogia Plena, pela Faculdade de Filosofia, Ciências e Letras (FAFICA), de Catanduva, São Paulo.
} 
facts or phenomena whose causes we want to know, and of a qualitative approach, due to its subjective analysis. With the observation of the classes, it was possible to verify that the children really perpetrate the entire theoretical development process described by both Piaget and Vygotsky; emphasizing the fusion of both theories at a given time, supporting the importance of the union of knowledge. It was concluded, therefore, that the knowledge and didactics of the mediating teacher make all the difference in the process of training a reader and, consequently, in the type of human being that will be inserted in social life.

Keywords: Piaget, Vygotsky, reading, children's literature, didactic.

\section{INTRODUCTION}

To speak of reading is to accept the possibility of the existence of two worlds - the real and the imaginary - and when considering this statement, we understand that reading is not an easy activity, as it requires premature stimuli to consolidate this practice in the course of the time. Reading is the most responsible for the contribution of each human being formation, as it influences, expands, and diversifies the subject's interpretations concerning life and the world. It is from the reader-world interaction that thoughts are formatted, questions are raised, reflection and the construction of their concepts and lessons are dynamized (KRUG, 2015).

In the past two decades, Brazil has experienced a series of changes in its education system seeking to contribute to the quality of education and the increase in learning rates. The core of these changes is always the work done in the classroom (OLIVEIRA; CARVALHO, 2018). Despite all efforts, the students' learning results appear to remain below expectations, especially in terms of reading. According to the latest survey 'Retratos da Leitura no Brasil, 4th edition', of 2015, carried out by Instituto Brasileiro de Opinião Pública e Estatística (Ibope) at the request of Instituto Pró-Livro, 44\% of the Brazilian population does not read and 30\% never bought a book. Reading practice ranked 10th when asked about leisure activities; losing even to previous editions of the same survey. This reflects the impoverishment of the Brazilian debate. 
Contact with reading should start at an early age when children are more flexible and with more keen curiosity. From the moment of insertion of this child in the schooling process, confirming the understanding that schooling does not mean literacy, an extraschool, and intra-family union must be consolidated aiming at the concretization of the reading practice in the minor. For this, the examples at home, coming from parents and family, and the enthusiasm of the mediating teacher at school, fall on the solidification of this reading curiosity as a long-standing characteristic. Both need to conform with the desire to achieve their goal; after all, only those who relate to books, in a precious way, will have the power to generate new good readers (KRUG, 2015).

In the process of collaborating in this task, studies demonstrate the effectiveness of developmental psychology applied in the classroom (BLAKE, POPE, 2008). For theoretical purposes, knowledge is conceived as symbolic and material production that takes place in interaction. By interaction, we understand the subject's contact with himself through reflection and assimilation, or the subject's contact with another subject. Concerning the ideas of Jean Piaget (1975), there must be at least two subjects and one object, so that, in school contact, the student-subject with a teachersubject, interacting about an object, they offer countless possibilities for intellectual construction to both parties. Under Lev Vygotsky's (1934) bias, every child needs a particular moment to assimilate and accommodate new information.

It is quite evident that the theories developed by Piaget and Vygotsky corroborate the awakening of reading in early childhood. Therefore, since children do not, however, have the reading ability, they need an adult who promotes this interaction so that, later, they will assimilate the new knowledge. It is enough for the teacher to create strategies so that the incentive hitherto offered is not lost with time and with new discoveries. It is important to mention that in the technological world, discoveries are many and they are fast. As a result, the pedagogical strategies outlined by the teacher are fully reflected in the motivational development of the young reader.

It is also worth noting that the books produced for this early childhood age group are designed with an image in mind and not reading, precisely because they are an audience that does not read yet. However, the material used for the activities described 
below presents an opposite universe: it contains verbal and non-verbal texts. The verbal text is justified by the fact that there is an adult to serve as an example and to conduct the interaction, according to Piaget explains; in relation to the non-verbal text, it seeks to promote a moment to awaken creativity and assimilate what was heard during the adult's oral reading, according to Vygotsky.

This research aims, therefore, to analyze a child's first contact with the book and raise hypotheses about the impacts that this practice causes when minors are exposed to reading activity in early childhood. For that, we will prioritize the school environment and the figure of the teacher, since i) it is evident that the task of the school is to teach human beings to read; ii) the target audience of this research, although not literate, depends on the help of the teacher, and iii) the well-trained and qualified professional has the power to transform lives.

\section{THE CONSTRUCTION OF KNOWLEDGE IN THE THEORIES OF JEAN PIAGET AND LEV VYGOTSKY}

Even with all the theoretical and educational advances achieved over decades, there is still a divergence of thought between teachers and researchers regarding the application of developmental psychology in the classroom. Developed by Jean Piaget and Lev Vygotsky, it is defined as the study of biological, cognitive, and socioemotional changes that humans undergo as they age. In this sense, it is known that, when applied by the teacher, students' performance increases significantly (BLAKE; POPE, 2008).

The starting line for the development proposal from the Piagetian perspective was the observation of the mistakes made by the children, or, in other words, the imbalance between the subject and the object. For Jean Piaget, children do not inherit readymade mental capacities, the subject incorporates the object as a means of knowledge; this classifies his theory through the constructivist perspective, as it expresses learning as construction. Thus, the act of developing in four stages is shown: sensorimotor (from 0 to 2 years), pre-operative (between 2 and 7 years), concrete operational (from 8 to 12 years), and formal operational (from 12 years old). 
Piaget demonstrates the importance of developing a skill in which transformation takes place without changing the essence of the individual. It describes the circumstance as an adaptation to the environment, followed by assimilation and accommodation. When an individual incorporates a new object or new patterns into the structures already known to him, the 'assimilation' skill develops. While employing what has been assimilated to adjust it to new possibilities of use, 'accommodation' is carried out. This way, from Jean Piaget's point of view, it can be seen that knowledge is built from the inside out.

On the other hand, from a Vygotsky perspective, development does not precede socialization, although social relationships and structures lead to the development of mental functions. For Vigostki, there is a gap between the autonomy of the learning subject and what he still needs to perform other activities. That is, ZPD (Zone of Proximal Development), instruction and learning. When children are in this area, they may succeed depending on the quality of instructional assistance that is offered to them.

Social interactions play an important role in children's learning. Vygotsky divides social discourse into three fronts: private, social, and internal. They are responsible for all instructions that the child receives from adults. The private discourse is in charge of allowing possibilities for the child to appropriate what the adult said and try to apply it to a similar situation. The results of social discourse converted into private discourse generate internal discourse, which corresponds to the capacity developed by the human being to reach a higher level of thinking (HUIIT, 2000).

Generally speaking, Piaget and Vygotsky share the same object of study: developmental psychology, albeit from different points of view. For both, learning takes the subject to a higher level of thought and reflection. However, for Piaget, this construction is carried out with a focus on the subject, while for Vygotsky, the focus falls on social interaction. 


\section{THE USE OF LITERATURE FOR EARLY CHILDHOOD}

Literature is a word of Latin origin and refers to the idea of instruction, of knowledge related to the art of reading and writing (AGUIAR E SILVA, 1969). With the development of writing in the 7th century $\mathrm{BC}$ and the creation of the Gutenberg press in the 15th century, it started to play an even more important role for society as a whole. At first, it collaborated as a support for the recording of what had previously been classified as oral tradition literature.

During antiquity, classical literature, projected from the perspective of myth and fantasy, emerged in the East and extended throughout the European territory (TORTELLA et al., 2016). Faced with the Middle Ages scenario, it started to employ an ideational view of the world, incorporating the duel between good and evil in his narratives; a dichotomy that feeds plots to this day. Between comings and goings, the rise of the bourgeoisie, the industrialization process taking over urban areas, the idea of children's literature was projected to establish behavioral standards required by the new bourgeoisie (PEREIRA, 2007). Even today, the objective is to transmit values to children through children's literature. In this sense, the literary market has offered ample possibility of inserting new themes that until then were not commercialized for such an audience. Currently, it is possible to find plots that range from vacation trips with the family to cases of bullying and neurodegenerative diseases (OLIVEIRA, 2019; 2019a). It appears, therefore, that it is a total collaborator in the process of building human beings since it can be considered an interdisciplinary territory (SALDANHA; AMARILHA, 2018).

It is known that the practice of reading occupies an essential space in the life of the human being. However, it took some time to consolidate itself as a comprehensive social and cultural phenomenon (ORLANDO; LEITE, 2018) and to abandon the traditional perception of being a mere process of decoding and oralizing writing (GROTTA, 2000). Thus, the dialogue around reading is based on the idea that the act of reading is not limited to the decoding of the written code, but is preceded and extended by the reader's knowledge of the world (FREIRE, 2011). It can be seen, therefore, that the individual reader started to play an active role in this process, 
supporting the construction of the subject as a historical and social being. In this way, education and literature become fundamental in the construction of a humanized conscience, which values the human being and which perceives how to act in society.

Assigning a value to this reasoning, children's literature is, therefore, a path that leads the child to develop imagination, emotions, and feelings in a pleasurable and meaningful way in the face of the surrounding reality. Bakhtin (1992) points out children's literature as a motivating and challenging instrument, capable of transforming the individual into an active subject, responsible for his learning, who knows how to understand the context in which he lives and modify it according to his own need. Upon hearing or reading a story, the child can comment, inquire, doubt and/or discuss the narrative. When babies, still incapable of speaking, lullabies, swirling songs, short narratives about nature and objects, with simple languages, short and everyday phrases, amuse the audience by stimulating them in such a way that they start to show their interest for the stories clapping, imitating, smiling and even expressing fear.

For the child in early childhood, collective-social reading is fundamental for their development in society. In addition to being a very interesting way of working with playfulness, through narratives that help in the development of children's creativity and their interpretative skills, it awakens the sense of citizenship, making the child a more humanized being.

\section{METHODOLOGY}

The present research unfolds under the bias of the inductive method. In inductive reasoning, the generalization elaborated, the result of particular findings, derives from observations of cases of reality (PRODANOV, 2013). The importance of induction as a research methodology was reinforced and started to be proposed as a more appropriate method for research in the social sciences (GIL, 2008). The inductive method starts from the observation of facts or phenomena whose causes we want to know. In this sense, the applied approach was the observational one. 
On the one hand, it can be considered as the most primitive and, consequently, the most imprecise. However, on the other hand, it can be considered as one of the most modern, since it is the one that most enables the highest degree of precision in the social sciences (GIL, 2008).

For data analysis purposes, the qualitative analysis technique was used, since it seeks to understand human phenomena, as it bases its analyzes on subjectivity so that the motivations, beliefs, values, and representations found are taken into account. in social relations (KNECHTEL, 2014).

The observation of this research was carried out at CEMEI of Proinfância "Professora Izilda do Carmo Calseverini de Oliveira", in the municipality of Tabapuã, São Paulo, Brazil. The activities were carried out in the space of a school week (as detailed in Table 1) and the public to be observed was composed of five children, 2 of whom were 2 years old and 3 of 3 years old, from the maternal year I.

The proposal was to present the book "A Boca do Sapo" (The mouth of the Frog), by Mary França and Eliardo França, during the subsequent five days of class and observe how the theories of Jean Piaget and Lev Vygotsky contributed to the development of minors in the face of the plot, focusing aspects such as: (i) children's curiosities; (ii) immediate and lasting interest in relation to the book object; (iii) changes in behavior after contact with the book and its narratives. To carry out the activities, the popular song “O Sapo Não Lava o Pé” ( The Frog Doesn't Wash His Feet) was also used.

In Table 1, it is possible to perceive a greater outline about the planning of the week of reading activities, in which, in addition to measuring the amount of time worked each day, the objectives and the development of the classes are also described.

\section{Table 1: Lesson planning}

\begin{tabular}{l|lll|l} 
Weekday & Time Activity & Objectifes & Development
\end{tabular}




\begin{tabular}{|c|c|c|c|c|}
\hline Monday & $60 \mathrm{~min}$. & Book presentation & $\begin{array}{l}\text { Promote the first } \\
\text { contact with the } \\
\text { book object. }\end{array}$ & $\begin{array}{l}\text { The mediating } \\
\text { teacher } \\
\text { presented the } \\
\text { book, let the } \\
\text { children handle it } \\
\text { and, finally, read } \\
\text { the story. }\end{array}$ \\
\hline Tuesday & $60 \mathrm{~min}$. & $\begin{array}{l}\text { Meeting the } \\
\text { characters }\end{array}$ & $\begin{array}{l}\text { Instigate the } \\
\text { desire and the } \\
\text { curiosity to keep } \\
\text { in touch with the } \\
\text { book through the } \\
\text { characters. }\end{array}$ & $\begin{array}{l}\text { The children had } \\
\text { the opportunity to } \\
\text { physically feel the } \\
\text { book once again } \\
\text { and established } \\
\text { greater contact } \\
\text { with each other } \\
\text { by getting to know } \\
\text { the characters in } \\
\text { the story. This } \\
\text { time, made with } \\
\text { scrap metal by } \\
\text { the teacher. }\end{array}$ \\
\hline Wednesday & $60 \mathrm{~min}$. & $\begin{array}{l}\text { Retelling and } \\
\text { discussing the } \\
\text { storyline }\end{array}$ & $\begin{array}{l}\text { Explore the } \\
\text { interpretation of } \\
\text { the plot; } \\
\text { Reinforce moral } \\
\text { and social } \\
\text { values, such as } \\
\text { respect and } \\
\text { tolerance. }\end{array}$ & $\begin{array}{l}\text { The children were } \\
\text { placed in a circle } \\
\text { and the mediating } \\
\text { teacher talked } \\
\text { about the text and } \\
\text { explored its } \\
\text { interpretation, as } \\
\text { well as possible } \\
\text { explored values } \\
\text { for living in } \\
\text { society. }\end{array}$ \\
\hline
\end{tabular}




\begin{tabular}{|c|c|c|c|c|}
\hline Thrusday & $60 \mathrm{~min}$. & $\begin{array}{l}\text { Retelling and } \\
\text { singing }\end{array}$ & $\begin{array}{l}\text { Promote ways } \\
\text { for children to } \\
\text { retell the story } \\
\text { within their } \\
\text { linguistic and } \\
\text { phonetic limits; } \\
\text { Introduce } \\
\text { popular songs. }\end{array}$ & $\begin{array}{l}\text { The story was } \\
\text { retold again, } \\
\text { however, with the } \\
\text { help of the } \\
\text { children. In the } \\
\text { sequence, they } \\
\text { heard, learned } \\
\text { and sang the } \\
\text { popular song "O } \\
\text { Sapo Não Lava o } \\
\text { Pé" (The Frog } \\
\text { Doesn't Wash His } \\
\text { Feet). }\end{array}$ \\
\hline Friday & 60 min. & $\begin{array}{l}\text { Reading, recycling } \\
\text { and recreating }\end{array}$ & $\begin{array}{l}\text { Work on the } \\
\text { importance of } \\
\text { recycling; } \\
\text { Reinforce the } \\
\text { richness of the } \\
\text { book in our life. }\end{array}$ & $\begin{array}{l}\text { Everyone saw } \\
\text { how to produce a } \\
\text { frog using scrap } \\
\text { metal and } \\
\text { received } \\
\text { recycled frog to } \\
\text { retell the story at } \\
\text { home. } \\
\text { activity ended, } \\
\text { allowing the little } \\
\text { ones to feel the } \\
\text { book in their } \\
\text { hands in order to } \\
\text { reinforce their } \\
\text { interest in the } \\
\text { material, which } \\
\text { brought them so }\end{array}$ \\
\hline
\end{tabular}


much wealth of knowledge.

Source: Authors

\section{RESULTS AND DISCUSSION}

The first day was chosen for the children to create an atmosphere and get used to it. The carpet, the objects, the movements were all intentional and thought-provoking; a way of guiding them playfully. The teacher introduced the character Frog and subsequently allowed each of the little ones to have their first contact with the book; they handled it, observed it, expressed in their own way everything they felt at that moment.

It is quite pertinent to highlight that in this first contact of children with literature, the full application of the Vygotskian proposal: by promoting the new environment and instigating the curiosity of the little ones, the fantasy of the abstract starts to take shape by materializing the activity; especially in relation to the book object. Therefore, reactions of the most diverse arise, citing observation, concentration, interaction, the way of expressing what they feel, etc.

The first contact awakens the imaginary and the fictitious in children so that they can associate them with their realities. Observation, the result of curiosity, is noticeable. When the reading started, the children not only pay attention to the characteristics of the characters but also notice the voice shift of the mediating teacher performing phonetic changes when exploring the peculiarities of each animal in the narrative. The concentration stands out as the children start to take ownership of the plot and feel part of the story, that is, it arouses in them the interest to interact and express themselves in defense of one or the other character. At this stage, it is essential that the mediating teacher gets an accurate look, as the process of creating a subject, several of them, is really in operation. 
In order to collaborate even more to materialize what had previously seemed so abstract, the mediating teacher presented, brilliantly, the characters of the history made from scrap metal. This type of activity concatenates principles outlined by Piaget with regard to the construction of meaning and the internalization of knowledge since it is an audience at the beginning of the preoperative stage. The concern was to offer children a way to install logical sense even before language, promoting interaction between sensory and motor activities with the environment, especially the sociocultural environment. Every response, be it an act directed at the outside world or an internalized act such as thought, takes the form of an adaptation or, better, a readaptation (PIAGET, 1923).

Following this line, it is up to the teachers to take advantage of this apprenticeship and provide opportunities for contact between the little ones and the book. After all, the book is no longer just a book, it is a fun friend; and reading is no longer just reading, it is a partner for new discoveries, configuring a new reality in the reality of each child's life.

Another enriching factor was to present a plot in which the main character, the Frog, suffered a certain prejudice due to the size of its mouth. At the time of reading, the children showed all kinds of sensation, shared the joke of other animals in relation to the frog, however, they ended up understanding the situation and learning values proposed by that literature. Based on the premise that a reading cannot be just a reading, the chosen work was totally linked to the curricular objectives and, more intrinsically, corroborating a greater good that is the development of attitudes in the human being as a social being.

The social affective progress presented by Vygotsky (1934) was more than noticeable. When asked in relation to what happened in the story, about the characters, the most fun moment, a sad moment, the children made sure that reading, when well oriented, is a valuable tool to start the social construction process of human beings. Metaphorically speaking, that little empty cup is gradually being filled with attitudes, values, a knowledge that when well oriented, will be agents of good in a more inclusive society. With the story, the children developed a look for respect and tolerance. 
The children's charm with the book, the story, the environment, the characters made from scrap metal was such that, when retelling stories in later situations, their eyes were filled with enthusiasm and attention. The rereading and retelling of the story promote the freedom of the little ones to present their ideas and feelings showing us that the child really is the fruit of what is offered to them; therefore, drawing a parallel between theories, this is where Piaget and Vygotsky meet: language. For the first, after listening, the child internalizes (1975); for the second, the child needs the means to internalize and expose (1934).

In fact, development at this stage is not just up to the school. In this sense, the teacher's attentive gaze was noticed when offering a frog made of scrap for each child's home. The objective was for them to maintain the habit of retelling the story to their families, strengthening primary mechanisms of speech, and, consequently, enriching this skill every day. Many children express their appreciation for the frog and offered to tell the story of the pet to their parents and siblings.

\section{CONCLUSION}

In addition to what has been verified in relation to the importance of applying the theories of Jean Piaget and Lev Vygotsky pre and post-class in order to consolidate a motivating tool in the awakening to reading in early childhood, two other factors are important as parameters of final consideration: the child's motivation for the book with reading from an early age; and the role of the teacher as a mediator for such motivation. On the 'pro-teacher' merit, that idea that only a teacher can speak during class needs to end. The child urged to become the center of the class, the protagonist of learning. Everything has changed in the last few years, from the way we buy our clothes in the way we watch a video. However, education continues in the same format as our grandparents. It is crucial that teachers innovate their pedagogy within the classrooms, it is essential that they think about the evolution of the little ones in a current and integral way, offering them principles of friendship with the book and with reading. Creating a generation without aversion to the book, the world is transformed in the broadest sense of coexistence. 


\section{REFERENCES}

AGUIAR E SILVA, V.M. Teoria da Literatura. São Paulo: Almedina, 1968.

BAKHTIN, M. Os gêneros do discurso. In.: Estética da criação verbal. Trad. Maria Ermantina Galvão Gomes e Pereira. São Paulo: Martins Fontes, 1992. p. 277-326, 1952-1953.

BLAKE, B.; POPE, T. Developmental Psychology: Incorporating Piaget's and Vygotsky's Theories in Classrooms. Journal of Cross-Disciplinary Perspectives in Education, v. 1, n. 1, p. 59-67, mai. 2008.

FREIRE, P. Pedagogia da Autonomia: saberes necessários à prática educativa. 43. ed. São Paulo: Paz e Terra, 2011.

GIL, A. C. Métodos e Técnicas de Pesquisa Social. 6 ed. São Paulo: Atlas, 2008.

GROTTA, E. C. B. Processo de formação do leitor: relato e análise de quatro histórias de vida. Dissertação de Mestrado - Faculdade de Educação, Unicamp, 2000.

HUIIT, W. G. A constructivist approach to learning (PowerPoint). CA: Valdosta State University. 2000.

KNECHTEL, M. R. Metodologia da pesquisa em educação: uma abordagem teórico-prática dialogada. Curitiba: Intersaberes, 2014.

KRUG, F. S. A importância da leitura na formação do leitor. Revista de educação do Ideau, v. 10, n. 22, jul-dez 2015. ISSN: 1809-6220.

OLIVEIRA, A. C. P. D.; CARVALHO, C. P. D. Gestão escolar, liderança do diretor e resultados educacionais no Brasil. Revista Brasileira de Educação, v. 23, 2018. ISSN 1413-2478 
OLIVEIRA, L. R. A literatura como recurso pedagógico na divulgação do conhecimento sobre a doença de Alzheimer. Revista Científica Multidisciplinar Núcleo do Conhecimento. Ano 4, v. 5, p. 117-125, mar 2019. ISSN: 2448-0959.

OLIVEIRA, L. R. A literatura infantil no preparo das crianças e jovens para o convívio com pacientes da doença de Alzheimer. In: Vilmar Baggio (org.). Vozes da Educação. 2. ed. São Paulo: Diálogo Freiriano, 2019a, v. 6, p. 369-385.

ORLANDO, I. R.; LEITE, S. A. A. Formação de leitores: a dimensão afetiva na mediação da família. Psicol. Esc. Educ., Maringá, v. 22, n. 3, p. 511-518, dez. 2018. DOI 10.1590/2175-35392018039282.

PEREIRA, M.S. A importância da literatura infantil nas séries iniciais. Revista Eletrônica de Ciências da Educação, Campo Largo, v.6, n.1, jun 2007.

PIAGET, J. A representação do mundo na criança. Rio de Janeiro: Record. 1975.

PRONADOV, C. C. Metodologia do Trabalho Científico: métodos e técnicas da pesquisa e do trabalho acadêmico. Ed. 02. Novo Hamburgo: Feevale, 2013.

SALDANHA D. M. L. L.; AMARILHA, M. O ensino da literatura no curso de Pedagogia: uma prática necessária. Educar em Revista, Curitiba, Brasil, v. 34, n. 72, p. 151-167, nov./dez 2018. DOI 10.1590/0104-4060.62735.

TORTELLA, J. C. B.; SOUZA, A. B.; FARIA, A. P.; ZAPIO, C. C. Histórias e memórias na educação infantil: um elo entre literatura infantil, PNBE e prática pedagógica. Nuances: Estudos sobre Educação, Presidente Prudente, Brasil, v.27, n.2, 134-151, mai./ago. 2016.

VIGOTSKI, L.S. Pensamento e linguagem. São Paulo: Martins Fontes. 2008.

Submitted: February, 2020.

Approved: June, 2020. 